\title{
Structural Transformation from Trinuclear Linear to Tetranuclear Cubane Heterobimetallic Selenium Compounds. Structure and Optical Linearities of $\left[\mathrm{Et}_{4} \mathrm{~N}\right]_{2}\left[\left(\mu-\mathrm{WSe}_{4}\right)(\mathrm{CuCl})_{2}\right]$
}

\author{
Shu-Lei Liu ${ }^{\mathrm{a}}$, Taike Duan ${ }^{\mathrm{a}}$, Qian-Feng Zhang, ${ }^{\mathrm{a}, \mathrm{b}}$, and Wa-Hung Leung ${ }^{\mathrm{c}}$ \\ ${ }^{a}$ Institute of Molecular Engineering and Applied Chemistry, Anhui University of Technology, \\ Ma'anshan, Anhui 243002, P. R. China \\ b State Key Laboratory of Coordination Chemistry, Nanjing University, Nanjing 210009, P. R. China \\ ${ }^{c}$ Department of Chemistry, The Hong Kong University of Science and Technology, Clear Water Bay, \\ Kowloon, Hong Kong, P. R. China
}

Reprint requests to Dr. Qian-Feng Zhang and Prof. Wa-Hung Leung. Fax: +86-555-2312041. E-mail: zhangqf@ahut.edu.cn and chleung@ust.hk

Z. Naturforsch. 2009, 64b, 209-214; received September 22, 2008

\begin{abstract}
Reactions of $\left[\mathrm{Et}_{4} \mathrm{~N}\right]_{2}\left[\mathrm{WSe}_{4}\right]$ with two equivalents of $[\mathrm{CuX}]$ powder gave trinuclear linear compounds $\left[\mathrm{Et}_{4} \mathrm{~N}_{2}\left[(\mu\right.\right.$-WSe 4$\left.)(\mathrm{CuX})_{2}\right](X=\mathrm{Cl} \mathbf{1}, \mathrm{Br} 2)$. Treatment of 1 or 2 with $\mathrm{PPh}_{3}$ in $\mathrm{CH}_{2} \mathrm{Cl}_{2}$ resulted in the formation of tetranuclear cubane-like compounds $\left(\mu_{3}-X\right)\left(\mu_{3}-\mathrm{WSe}_{4}\right)\left(\mathrm{CuPPh}_{3}\right)_{3}(X=\mathrm{Cl}$ $\mathbf{3}, \mathrm{Br}$ ). The structures of the heterobimetallic selenium compounds $\mathbf{1}$ and $\mathbf{4} \cdot \mathrm{MeCN}$ were confirmed by single-crystal X-ray diffraction. The nonlinear optical properties of $\mathbf{1}$ were investigated at $\lambda=$ $532 \mathrm{~nm}$ with a pulse width of $7 \mathrm{~ns}$.
\end{abstract}

Key words: Synthesis, Crystal Structure, Heteroselenometallic Compound, Nonlinear Optical Properties

\section{Introduction}

The chemistry of the heteroselenometallic compounds containing anions $\left[\mathrm{MSe}_{4}\right]^{2-}(\mathrm{M}=\mathrm{Mo}, \mathrm{W})$ has received attention owing to their structures and nonlinear optical (NLO) properties in recent years [1]. Compared with heterothiometallic compounds, it is reasonably speculated that, similar to their sulfur counterparts, selenium-containing compounds may also possess large NLO properties [2,3]. An important reason is that the heavy atom effect may result in effective improvement of NLO properties [4]. Another important reason is that selenium-containing compounds have important applications as precursors for low band gap semiconductors and in nonlinear optics [5]. In this connection, we set out to isolate new heteroselenometallic compounds from reactions between tetraselenometalate anions and coinage metal cations, and further to investigate the structure-property relationship of this class of compounds. A number of heteroselenometallic compounds have been successfully isolated to date. Their structural types include linear, butterfly, cubane, incomplete cubane, coplanar T-frame and open crossframe, crown, cage, and pin-wheel shapes [6-16].
Among these heteroselenometallic compounds, the variation of structural types mainly depends on the number of coinage metal atoms bound to the tetrahedral $\left[\mathrm{MSe}_{4}\right]^{2-}$ moiety, which probably influences the NLO properties of the compounds $[14,16]$. Herein, we report the syntheses of trinuclear linear compounds $\left[\mathrm{Et}_{4} \mathrm{~N}\right]_{2}\left[\left(\mu-\mathrm{WSe}_{4}\right)(\mathrm{Cu} X)_{2}\right](X=\mathrm{Cl} \mathbf{1}, \mathrm{Br} 2)$ and their structural transformation to tetranuclear cubane-like compounds $\left(\mu_{3}-X\right)\left(\mu_{3}-\mathrm{WSe}_{4}\right)\left(\mathrm{CuPPh}_{3}\right)_{3}(X=\mathrm{Cl} \mathrm{3}$, $\mathrm{Br} 4)$. Their structures and spectroscopic properties along with NLO properties were investigated.

\section{Experimental Section}

\section{General}

All manipulations were conducted using Schlenk techniques under an atmosphere of nitrogen. All reagents, unless otherwise stated, were purchased as analysis grade and were used without further purification. $\left[\mathrm{Et}_{4} \mathrm{~N}\right]_{2}\left[\mathrm{WSe}_{4}\right]$ was prepared by a modification of the literature method [17]. Infrared spectra were recorded on a Digilab FTS-40 spectrophotometer with use of pressed $\mathrm{KBr}$ pellets. Electronic spectra were obtained on a Hitachi U-3410 spectrophotometer. All elemental analyses were carried out using a PerkinElmer $2400 \mathrm{CHN}$ analyzer. 


\section{Syntheses}

\section{$\left[\mathrm{Et}_{4} \mathrm{~N}_{2}\left[\left(\mu-\mathrm{WSe}_{4}\right)(\mathrm{CuCl})_{2}\right](\mathbf{1})\right.$}

To a solution of $\left[\mathrm{Et}_{4} \mathrm{~N}\right]_{2}\left[\mathrm{WSe}_{4}\right](190 \mathrm{mg}, 0.25 \mathrm{mmol})$ in DMF $(15 \mathrm{~mL})$ was added a suspension of $\mathrm{CuCl}(50 \mathrm{mg}$, $0.50 \mathrm{mmol})$ in $\mathrm{MeCN}(3 \mathrm{~mL})$. The mixture was stirred at r.t. for $1 \mathrm{~h}$, during which time the color gradually changed from purple to red and a precipitate formed. The precipitate was re-dissolved upon addition of $1 \mathrm{~mL}$ 2,6-dimethylpyridine to the reaction mixture. The resulting red solution was stirred for additional $0.5 \mathrm{~h}$ and subsequently filtered to remove small amounts of a red precipitate. Slow addition of THF induced the crystallization of $\mathbf{1}$ as red blocks suitable for X-ray analysis. Yield: $134 \mathrm{mg}(56 \%)$. - Anal. for $\mathrm{C}_{16} \mathrm{H}_{40} \mathrm{~N}_{2} \mathrm{Cl}_{2} \mathrm{Cu}_{2}$ $\mathrm{Se}_{4} \mathrm{~W}$ : calcd. C 20.1, H 4.21, N 2.92; found C 20.2, H 4.17, N 2.90. - UV/Vis (DMF, nm): $\lambda=361$ (sh), 484(br).

\section{$\left[E t_{4} \mathrm{~N}_{2}\left[\left(\mu-\mathrm{WSe}_{4}\right)(\mathrm{CuBr})_{2}\right](2)\right.$}

Compound $\mathbf{2}$ was prepared similarly as described for $\mathbf{1}$ using $\mathrm{CuBr}$ (72 mg, $0.5 \mathrm{mmol}$ ) instead of $\mathrm{CuCl}$. Red microcrystals were obtained in a yield of $59 \%(155 \mathrm{mg})$. - UV/Vis (DMF): $\lambda=364$ (sh), 487(br) nm. - Anal. for $\mathrm{C}_{16} \mathrm{H}_{40} \mathrm{~N}_{2}$ $\mathrm{Br}_{2} \mathrm{Cu}_{2} \mathrm{Se}_{4} \mathrm{~W}$ : calcd. C 18.4, H 3.85, N 2.68; found C 18.2, H 3.88, N 2.65.

\section{$\left(\mu_{3}-X\right)\left(\mu_{3}-W_{4} e_{4}\right)\left(\mathrm{CuPPh}_{3}\right)_{3}(X=\mathrm{Cl} \mathrm{3,Br} 4)$}

To a slurry of 1 (96 mg, $0.10 \mathrm{mmol})$ or $2(105 \mathrm{mg}$, $0.10 \mathrm{mmol})$ in DMF ( $3 \mathrm{~mL}$ ) was added a solution of $\mathrm{PPh}_{3}$ (157 mg, $0.60 \mathrm{mmol})$ in $\mathrm{CH}_{2} \mathrm{Cl}_{2}(15 \mathrm{~mL})$, and the mixture was stirred for $4 \mathrm{~h}$ at r.t. The resulting orange-red solution was filtered to remove small amounts of an orange precipitate. Orange-red crystals of $\mathbf{3}$ or $\mathbf{4}$ were obtained by layering the filtrate with $\mathrm{MeCN}$. For 3: Yield: $114 \mathrm{mg}(51 \%)$. UV/Vis $\left(\mathrm{CH}_{2} \mathrm{Cl}_{2}\right): \lambda=325$ (s), 459 (br), 498 (sh) nm. - Anal. for $\mathrm{C}_{54} \mathrm{H}_{45} \mathrm{P}_{3} \mathrm{ClCu}_{3} \mathrm{Se}_{4} \mathrm{~W} \cdot\left(\mathrm{C}_{2} \mathrm{H}_{3} \mathrm{~N}\right)$ : calcd. C 43.3, $\mathrm{H} 3.11$, $\mathrm{N} 0.90$; found C 43.1, H 3.13, N 0.88. For 4: Yield: $136 \mathrm{mg}$ (57\%). - UV/Vis $\left(\mathrm{CH}_{2} \mathrm{Cl}_{2}\right): \lambda=321$ (s), 455 (br), 502 (sh) nm. - Anal. for $\mathrm{C}_{54} \mathrm{H}_{45} \mathrm{P}_{3} \mathrm{BrCu}_{3} \mathrm{Se}_{4} \mathrm{~W} \cdot\left(\mathrm{C}_{2} \mathrm{H}_{3} \mathrm{~N}\right)$ : calcd. C 42.1, H 3.03, N 0.88; found C 41.8, H 3.01, N 0.87.

\section{Crystal structure determination}

Single crystals of $\mathbf{1}\left(0.22 \times 0.16 \times 0.12 \mathrm{~mm}^{3}\right)$ and 4. $\mathrm{MeCN}\left(0.24 \times 0.17 \times 0.10 \mathrm{~mm}^{3}\right)$ were mounted in random orientation on glass fibers. Diffraction data were collected on a Bruker SMART Apex CCD diffractometer with $\operatorname{Mo} K_{\alpha}$ radiation $(\lambda=0.71073 \AA)$ at $296 \mathrm{~K}$ using an $\omega$ scan mode. The collected frames were processed with the software SAINT [18]. The data were corrected for absorption using the program SADABS [19]. Structures were solved by Direct Methods and refined by full-matrix least-squares on $F^{2}$ using the SHELXTL software package [20]. All nonhydrogen atoms were refined anisotropically. The positions
Table 1. Crystal data, data collection parameters and details of the structure refinement.

\begin{tabular}{|c|c|c|}
\hline Complex & $\mathbf{1}$ & 4.MeCN \\
\hline \multirow[t]{2}{*}{ Empirical formula } & $\mathrm{C}_{16} \mathrm{H}_{40} \mathrm{~N}_{2} \mathrm{Cl}_{2-}$ & $\mathrm{C}_{56} \mathrm{H}_{48} \mathrm{NP}_{3} \mathrm{Br}-$ \\
\hline & $\mathrm{Cu}_{2} \mathrm{Se}_{4} \mathrm{~W}$ & $\mathrm{Cu}_{3} \mathrm{Se}_{4} \mathrm{~W}$ \\
\hline Formula weight & 958.17 & 1598.085 \\
\hline Color, habit & red, block & orange-red, block \\
\hline Crystal size, $\mathrm{mm}^{3}$ & $0.23 \times 0.16 \times 0.12$ & $0.24 \times 0.17 \times 0.10$ \\
\hline Crystal system & monoclinic & rhombohedral \\
\hline Space group & $P 2_{1} / n$ & $R 3$ \\
\hline$a, \AA$ & $7.4856(1)$ & $15.8058(2)$ \\
\hline$b, \AA$ & $13.5186(2)$ & $15.8058(2)$ \\
\hline$c, \AA$ & $29.0547(5)$ & $23.9394(7)$ \\
\hline$\alpha$, deg & 90 & 90 \\
\hline$\beta, \operatorname{deg}$ & $92.864(1)$ & 90 \\
\hline$\gamma, \operatorname{deg}$ & 90 & 120 \\
\hline Volume, $\AA^{3}$ & $2936.51(8)$ & $5179.37(18)$ \\
\hline$Z$ & 4 & 3 \\
\hline Density (calc.), $\mathrm{g} \mathrm{cm}^{-3}$ & 2.17 & 1.54 \\
\hline Absorption coefficient, $\mathrm{mm}^{-1}$ & 10.5 & 5.4 \\
\hline Temperature, $\mathrm{K}$ & $296(2)$ & $296(2)$ \\
\hline$F(000) \mathrm{e}$ & 1808 & 2304 \\
\hline Radiation & \multicolumn{2}{|c|}{$-\operatorname{Mo} K_{\alpha}(\lambda=0.71073 \AA)-$} \\
\hline Reflections collected & 28928 & 15376 \\
\hline - independent & 6728 & 4740 \\
\hline$R_{\text {int }}$ & 0.052 & 0.026 \\
\hline Refls $[I \geq 2 \sigma(I)]$ & 4823 & 4135 \\
\hline Parameters refined & 252 & 207 \\
\hline Final $R 1 / w R 2$ (all data) $^{\mathrm{a}}$ & $0.062 / 0.076$ & $0.048 / 0.101$ \\
\hline $\begin{array}{l}\text { Weighting scheme; } \\
\text { - param. } a / b\end{array}$ & $0.0373 / 0.5140$ & $0.0629 / 3.2569$ \\
\hline Goodness of fit $(\mathrm{GoF})^{\mathrm{b}}$ & 1.02 & 1.10 \\
\hline$x$ (Flack) & - & $0.00(0)$ \\
\hline Final difference peaks, e $\AA^{-3}$ & $+0.96,-0.85$ & $+1.04,-1.17$ \\
\hline \multicolumn{3}{|c|}{$\begin{array}{l}{ }^{\mathrm{a}} R 1=\Sigma\left\|F_{\mathrm{o}}|-| F_{\mathrm{c}}\right\| / \Sigma\left|F_{\mathrm{o}}\right| ; w R 2=\left[\Sigma w\left(F_{\mathrm{o}}{ }^{2}-F_{\mathrm{c}}{ }^{2}\right)^{2} / \Sigma w\left(F_{\mathrm{o}}{ }^{2}\right)^{2}\right]^{1 / 2}, \\
w=1 /\left[\sigma^{2}\left(F_{\mathrm{o}}{ }^{2}\right)+(a P)^{2}+b P\right] \text { where } P=\left(F_{\mathrm{o}}{ }^{2}+2 F_{\mathrm{c}}{ }^{2}\right) / 3 ;{ }^{\mathrm{b}} \mathrm{GoF}= \\
{\left[\Sigma w\left(F_{\mathrm{o}}{ }^{2}-{F_{\mathrm{c}}}^{2}\right)^{2} /\left(N_{\mathrm{obs}}-N_{\text {param }}\right)\right]^{1 / 2} .}\end{array}$} \\
\hline
\end{tabular}

of all hydrogen atoms were generated geometrically $\left(\mathrm{C}_{s p^{3}-}\right.$ $\mathrm{H}=0.96$ and $\mathrm{C}_{s p^{2}}-\mathrm{H}=0.93 \AA$ ) and included in the structure factor calculations with assigned isotropic displacement parameters but were not refined. The $\mathrm{MeCN}$ solvent molecule in $4 \cdot \mathrm{MeCN}$ was refined isotropically with the hydrogen atoms. Crystal data, data collection parameters and details of the structure refinement are given in Table 1.

CCDC 703019/703020 contain the supplementary crystallographic data for this paper. These data can be obtained free of charge from The Cambridge Crystallographic Data Centre via www.ccdc.cam.ac.uk/data_request/cif.

\section{Optical measurements}

A DMF solution of $2.15 \times 10^{-3} \mathrm{~mol} \mathrm{dm}^{-3}$ of compound 1 was placed in a $1 \mathrm{~mm}$ quartz cuvette for optical measurements. The optical limiting characteristics along with nonlinear absorption and refraction was investigated with a linearly polarized laser light $(\lambda=532 \mathrm{~nm}$, pulse width $=7 \mathrm{~ns})$ generated from a Q-switched and frequency-doubled Nd : YAG 
Table 2. Selected bond lengths $(\AA)$ and bond angles (deg) for $\left[\mathrm{Et}_{4} \mathrm{~N}\right]_{2}\left[\left(\mu-\mathrm{WSe}_{4}\right)(\mathrm{CuCl})_{2}\right](\mathbf{1})$.

\begin{tabular}{|c|c|c|c|}
\hline$\overline{\mathrm{W}(1)-\mathrm{Se}(1)}$ & $2.3409(6)$ & $\mathrm{W}(1)-\mathrm{Se}(2)$ & $2.3385(6)$ \\
\hline $\mathrm{W}(1)-\operatorname{Se}(3)$ & $2.3399(6)$ & $\mathrm{W}(1)-\mathrm{Se}(4)$ & $2.3366(6)$ \\
\hline $\mathrm{Cu}(1)-\mathrm{Se}(1)$ & $2.3348(9)$ & $\mathrm{Cu}(1)-\mathrm{Se}(2)$ & $2.3337(9)$ \\
\hline $\mathrm{Cu}(2)-\mathrm{Se}(3)$ & $2.3396(8)$ & $\mathrm{Cu}(2)-\mathrm{Se}(4)$ & $2.3382(10)$ \\
\hline $\mathrm{Cu}(1)-\mathrm{Cl}(1)$ & $2.1599(16)$ & $\mathrm{Cu}(2)-\mathrm{Cl}(2)$ & $2.1668(17)$ \\
\hline $\mathrm{W}(1)-\mathrm{Cu}(1)$ & $2.6607(7)$ & $\mathrm{W}(1)-\mathrm{Cu}(2)$ & $2.6887(7)$ \\
\hline $\operatorname{Se}(2)-W(1)-\operatorname{Se}(1)$ & $110.39(2)$ & $\mathrm{Se}(3)-\mathrm{W}(1)-\mathrm{S}$ & $110.08(2)$ \\
\hline $\operatorname{Se}(4)-W(1)-\operatorname{Se}(1)$ & $108.80(3)$ & $\mathrm{Se}(2)-\mathrm{W}(1)-\mathrm{Se}(3)$ & $108.29(2)$ \\
\hline $\operatorname{Se}(4)-W(1)-\operatorname{Se}(2)$ & $109.46(2)$ & $\mathrm{Se}(4)-\mathrm{W}(1)-\mathrm{Se}(3)$ & $109.82(2)$ \\
\hline $\mathrm{Cu}(1)-\mathrm{Se}(1)-\mathrm{W}(1)$ & $69.37(2)$ & $\mathrm{Cu}(1)-\mathrm{Se}(2)-\mathrm{W}(1)$ & $69.43(2)$ \\
\hline $\mathrm{Cu}(2)-\mathrm{Se}(3)-\mathrm{W}(1)$ & $70.14(2)$ & $\mathrm{Cu}(2)-\mathrm{Se}(4)-\mathrm{W}(1)$ & $70.22(2)$ \\
\hline $\mathrm{Cl}(1)-\mathrm{Cu}(1)-\mathrm{Se}(1)$ & $124.69(5)$ & $\mathrm{Cl}(1)-\mathrm{Cu}(1)-\mathrm{Se}(2)$ & $124.52(5)$ \\
\hline $\mathrm{Se}(2)-\mathrm{Cu}(1)-\mathrm{Se}(1)$ & $110.77(3)$ & $\mathrm{Se}(4)-\mathrm{Cu}(2)-\mathrm{Se}(3)$ & $109.77(3)$ \\
\hline $\mathrm{Cl}(2)-\mathrm{Cu}(2)-\mathrm{Se}(3)$ & $124.29(6)$ & $\mathrm{Cl}(2)-\mathrm{Cu}(2)-\mathrm{Se}(4)$ & $125.92(6)$ \\
\hline
\end{tabular}

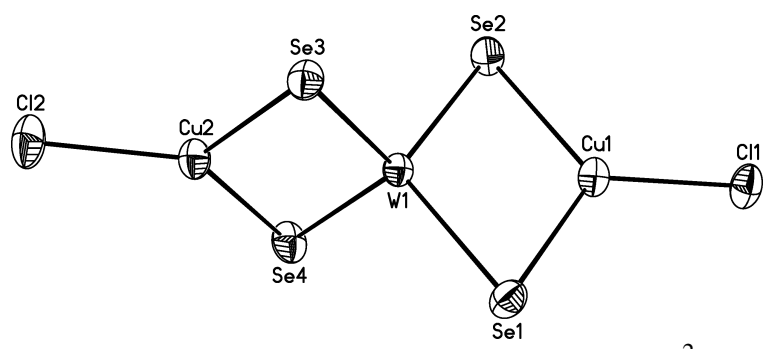

Fig. 1. A perspective view of the $\left[\left(\mu-\mathrm{WSe}_{4}\right)(\mathrm{CuCl})_{2}\right]^{2-}$ anion in 1 with the displacement ellipsoids drawn at the $40 \%$ probability level.

laser. The spatial profiles of the optical pulses were nearly Gaussian. The laser beam was focused with a $25 \mathrm{~cm}$ focallength focusing mirror. The radius of the laser beam waist was measured to be $30 \pm 5 \mu \mathrm{m}$ (half-width at $1 / \mathrm{e}^{2}$ maximum in irradiance). The incident and transmitted pulse energy were measured simultaneously by two Laser Precision detectors (RjP-735 energy probes) communicating to a computer via an IEEE interface [21].

\section{Results and Discussion}

Treatment of $\left[\mathrm{Et}_{4} \mathrm{~N}\right]_{2}\left[\mathrm{WSe}_{4}\right]$ in DMF with two equivalents of $\mathrm{CuCl}$ in $\mathrm{CH}_{3} \mathrm{CN}$ suspension resulted in a color change from purple to red and a red precipitate. Upon addition of 2,6-dimethylpyridine, the red precipitate was redissolved to give a clear red solution, from which red block-shaped crystals of $\left[\mathrm{Et}_{4} \mathrm{~N}\right]_{2}\left[\left(\mu-\mathrm{WSe}_{4}\right)\right.$ $\left.(\mathrm{CuCl})_{2}\right](\mathbf{1})$ were obtained in $56 \%$ yield. The bromide analog $\left[\mathrm{Et}_{4} \mathrm{~N}\right]_{2}\left[\left(\mu-\mathrm{WSe}_{4}\right)(\mathrm{CuBr})_{2}\right]$ (2) was isolated from $\mathrm{CuBr}$ powder under similar reaction conditions. It should be noted that bulk 2,6-dimethylpyridine acts as a co-solvent instead of a ligand in the present system. Addition of a small amount of 2,6-dimethylpyridine increases the solubility of the solid reactants, resulting in

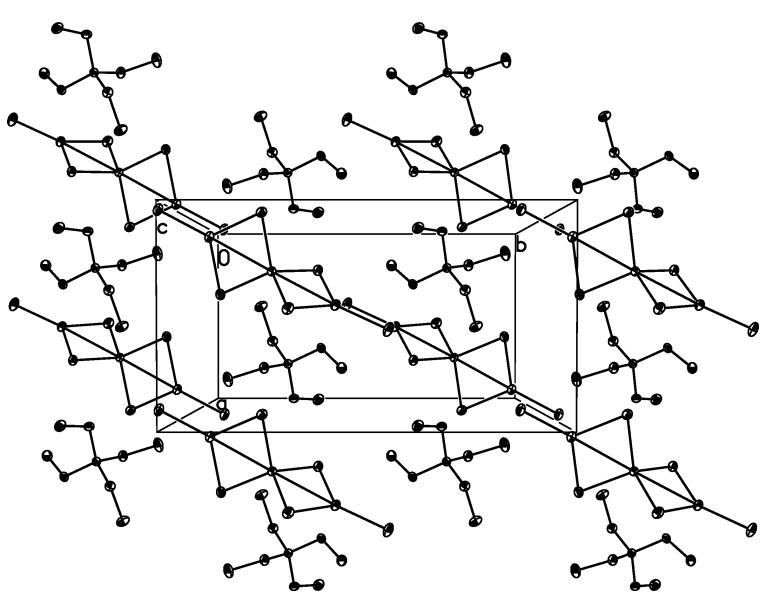

Fig. 2. Packing arrangement of $\left[\mathrm{Et}_{4} \mathrm{~N}\right]_{2}\left[\left(\mu-\mathrm{WSe}_{4}\right)(\mathrm{CuCl})_{2}\right]$ (1), showing well separated cations and anions.

the isolation of crystalline products in moderate yields. A similar synthetic route was used to prepare the cyanide-bridged three-dimensional framework cluster compound $\left\{\left[\mathrm{Et}_{4} \mathrm{~N}\right]_{2}\left[\left(\mu_{4}-\mathrm{WSe}_{4}\right) \mathrm{Cu}_{4}(\mathrm{CN})_{4}\right]\right\}_{n}$ [12] and crown-like cluster compounds $\left[\mathrm{Et}_{4} \mathrm{~N}\right]_{4}\left[\left(\mu_{5}-\mathrm{WSe}_{4}\right)\right.$ $\left.(\mathrm{Cu} X)_{5}(\mu-X)_{2}\right](X=\mathrm{Cl}, \mathrm{Br})[15]$.

The structure of $\mathbf{1}$ was confirmed by an X-ray diffraction study. The structure consists of well separated cations and anions, as shown in Fig. 2 as a view of the cell packing. The $\left[\mathrm{Et}_{4} \mathrm{~N}\right]^{+}$cations have normal bond lengths and angles, which will not be discussed here. The $\left[\left(\mu-\mathrm{WSe}_{4}\right)(\mathrm{CuCl})_{2}\right]^{2-}$ anion is shown in Fig. 1, and selected bond lengths and angles are given in Table 2. The trinuclear linear structure of the anion comprises two $\mathrm{CuCl}$ fragments ligating at opposite edges of the tetrahedral $\left[\mathrm{WSe}_{4}\right]^{2-}$ moiety. Similar structures of heteroselenometallic compounds such as anionic $\left[\left(\mu-\mathrm{WSe}_{4}\right)(\mathrm{CuCN})_{2}\right]^{2-}[8]$ and neutral $\left[\left(\mu-\mathrm{WSe}_{4}\right)\left(M \mathrm{PR}_{3}\right)_{2}\right]\left(M=\mathrm{Ag}, \mathrm{Au} ; R_{3}=\mathrm{Ph}_{3}\right.$, $\left.\mathrm{Me}_{2} \mathrm{Ph}\right)[6,22,23]$ have been previously reported. The tungsten atom in $\mathbf{1}$ has an essentially tetrahedral coordination geometry with the $\mathrm{Se}-\mathrm{W}-\mathrm{Se}$ angles ranging from $108.29(2)$ to $110.39(2)^{\circ}$. The average $\mathrm{W}-\mathrm{Se}$ bond length of 2.3390(6) $\AA$ is comparable to those in related heteroselenometallic compounds, but is obviously longer than those in free $\left[\mathrm{WSe}_{4}\right]^{2-}$ as expected. The geometry around the copper atoms is distorted trigonal planar with an average $\mathrm{Se}-\mathrm{Cu}-\mathrm{Se}$ angle of $110.27(3)^{\circ}$. The $\mathrm{W}-\mathrm{Cu}$ distances are 2.6607(7) and 2.6887(7) $\AA$, which are shorter than those in related heteroselenometallic compounds, indicative of a weak $\mathrm{W}^{\mathrm{VI}}-\mathrm{Cu}^{\mathrm{I}}$ interaction in $\mathbf{1}$. There is a small distortion 


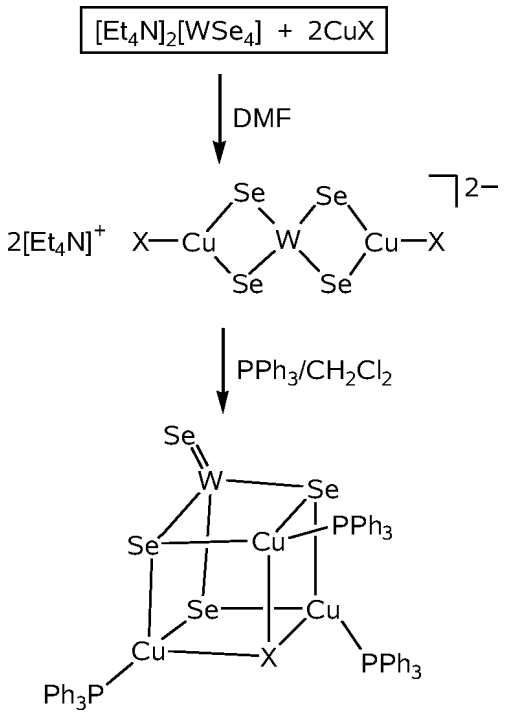

Scheme 1. Reactions of structural change from trinuclear linear to tetranuclear cubane compounds.

from ideal $D_{2 d}$ symmetry of the anion as a result of bending along the $\mathrm{Cl}-\mathrm{Cu}-\mathrm{W}-\mathrm{Cu}-\mathrm{Cl}$ axis that results in $\mathrm{a} \mathrm{Cu}-\mathrm{W}-\mathrm{Cu}$ angle of $177.43(2)^{\circ}$ and $\mathrm{W}-\mathrm{Cu}-\mathrm{Cl}$ angles of $176.90(6)$ and $177.36(6)^{\circ}$. The terminal $\mathrm{Cu}-\mathrm{Cl}$ bond lengths are 2.1599(16) and 2.1668(17) $\AA$, which agree well with those in $\left[\mathrm{Et}_{4} \mathrm{~N}_{4}\left[\left(\mu_{5}-\mathrm{WSe}_{4}\right)(\mathrm{CuCl})_{5}(\mu-\mathrm{Cl})_{2}\right]\right.$ (2.204(3) and 2.215(3) $\AA$ ) [15].

When compounds 1 and 2 were reacted with $\mathrm{PPh}_{3}$ in a mixed $\mathrm{CH}_{2} \mathrm{Cl}_{2} / \mathrm{DMF}$ solvent, the cubane-like compounds $\left(\mu_{3}-X\right)\left(\mu_{3}-\mathrm{WSe}_{4}\right)\left(\mathrm{CuPPh}_{3}\right)_{3}(X=\mathrm{Cl} \mathrm{3}, \mathrm{Br}$ 4) were obtained (see Scheme 1). The reactions involve the substitution of halide by the strong $\sigma$ donor $\mathrm{PPh}_{3}$ and structure transformation from trinuclear linear to tetranuclear cubane-like. This observation together with our previous report on cluster skeleton change from cross plane to cubane suggests that the cubane-like compounds are structurally stabilized in the presence of $\mathrm{PPh}_{3}$ and halide [12,24].

Compound $4 \cdot \mathrm{MeCN}$ was characterized by singlecrystal X-ray diffraction. A view of the structure of 4 is shown in Fig. 3, and selected bond lengths and angles are given in Table 3 . The crystal structure consists of a neutral cubane-like cluster $\left(\mu_{3}-\mathrm{Br}\right)\left(\mu_{3}-\right.$ $\left.\mathrm{WSe}_{4}\right)\left(\mathrm{CuPPh}_{3}\right)_{3}$ along with the solvent molecules. Both cubane-like compounds show bands at 2253 and $2251 \mathrm{~cm}^{-1}$ in their IR spectra, which are typical for the $\mathrm{CN}^{-}$stretching absorbance, indicative of the $\mathrm{MeCN}$ solvent molecules in the structures. The molecular cluster of $4 \cdot \mathrm{MeCN}$ crystallized in the rhombo-
Table 3. Selected bond lengths $(\AA)$ and bond angles (deg) for $\left(\mu_{3}-\mathrm{Br}\right)\left(\mu_{3}-\mathrm{WSe}_{4}\right)\left(\mathrm{CuPPh}_{3}\right)_{3}(4 \cdot \mathrm{MeCN})$.

\begin{tabular}{|c|c|c|c|}
\hline$\overline{\mathrm{W}(1)-\mathrm{Se}(1)}$ & $2.2692(13)$ & $\mathrm{W}(1)-\mathrm{Se}(2)$ & $2.3722(7)$ \\
\hline $\mathrm{Cu}(1)-\mathrm{Se}(2)$ & $2.3985(11)$ & $\mathrm{Cu}(1)-\mathrm{P}(1)$ & $2.230(2)$ \\
\hline $\mathrm{Cu}(1)-\mathrm{Br}(1)$ & $2.7896(14)$ & $\mathrm{W}(1)-\mathrm{Cu}(1)$ & $2.7643(9)$ \\
\hline $\operatorname{Se}(1)-\mathrm{W}(1)-\operatorname{Se}(2)$ & $110.246(18)$ & $\operatorname{Se}(2)-\mathrm{W}(1)-\operatorname{Se}(2)^{\# 1}$ & $108.685(19)$ \\
\hline $\mathrm{W}(1)-\mathrm{Se}(2)-\mathrm{Cu}(1)$ & $70.82(3)$ & $\mathrm{Cu}(1)^{\# 2}-\mathrm{Se}(2)-\mathrm{Cu}(1)$ & $85.90(5)$ \\
\hline $\mathrm{Se}(2)^{\# 2}-\mathrm{Cu}(1)-\mathrm{Se}(2)$ & $106.96(5)$ & $\mathrm{P}(1)-\mathrm{Cu}(1)-\mathrm{Br}(1)$ & $110.14(7)$ \\
\hline $\mathrm{Se}(2) \# 2-\mathrm{Cu}(1)-\mathrm{Br}(1)$ & $98.63(4)$ & $\mathrm{Se}(2)-\mathrm{Cu}(1)-\mathrm{Br}(1)$ & $98.62(4)$ \\
\hline $\mathrm{P}(1)-\mathrm{Cu}(1)-\mathrm{Se}(2)^{\# 2}$ & $120.15(7)$ & $\mathrm{P}(1)-\mathrm{Cu}(1)-\mathrm{Se}(2)$ & 118.41(7) \\
\hline $\mathrm{Cu}(1)-\mathrm{Br}(1)-\mathrm{Cu}(1)^{\# 1}$ & $71.72(4)$ & & \\
\hline
\end{tabular}

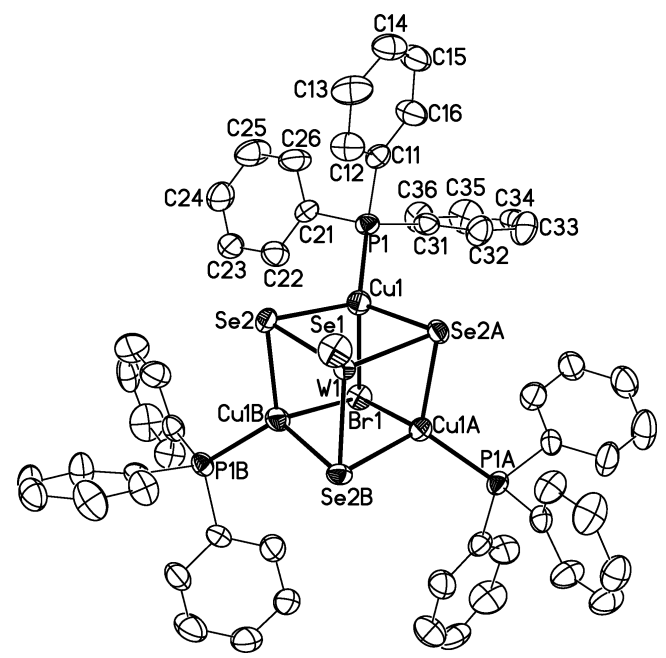

Fig. 3. Molecular structure of the cubane-like cluster compound $\left(\mu_{3}-\mathrm{Br}\right)\left(\mu_{3}-\mathrm{WSe}_{4}\right)\left(\mathrm{CuPPh}_{3}\right)_{3}(4)$ (displacement ellipsoids at the $40 \%$ probability level).

hedral space group $R 3$. The molecular structure possesses a crystallographic $C_{3}$ axis passing through the $\mathrm{Se}(1), \mathrm{W}(1)$ and $\mathrm{Br}(1)$ atoms and the $\mathrm{MeCN}$ molecule. The neutral compound contains a highly distorted cubane-like $\left[\mathrm{WCu}_{3} \mathrm{Se}_{3} \mathrm{Br}\right]$ cluster core and a $\mathrm{PPh}_{3}$ ligand bound to each copper atom. The $\mathrm{W}-\mathrm{Se}_{\mathrm{b}}$ (bridging) distance of 2.3722(7) $\AA$ is obviously longer than the $\mathrm{W}-\mathrm{Se}_{\mathrm{t}}$ (terminal) distance of 2.2692(13) $\AA$. The $\mathrm{Se}_{\mathrm{t}}-\mathrm{W}-\mathrm{Se}_{\mathrm{b}}$ angles are $c a .1 .6^{\circ}$ more obtuse than the $\mathrm{Se}_{\mathrm{b}}-\mathrm{W}-\mathrm{Se}_{\mathrm{b}}$ angles with an average $\mathrm{Se}-\mathrm{Cu}-\mathrm{Se}$ angle of $106.96(5)^{\circ}$. The average $\mathrm{W}-\mathrm{Cu}$ distance of 2.7643(9) $\AA$ in $4 \cdot \mathrm{MeCN}$ is slightly longer than that of $2.6747(7) \AA$ in $\mathbf{1}$, but is still shorter than the sum of the van der Waals radii of tungsten and copper atoms, which suggests that minor interactions may exist between two metal atoms. The $\mathrm{Cu}-\mathrm{Br}$ distance of $2.7896(14) \AA$ in $4 \cdot \mathrm{MeCN}$ agrees well with that of 2.797(1) $\AA$ in $\left(\mu_{3}-\mathrm{Br}\right)\left(\mu_{3}-\mathrm{MoSe}_{4}\right)\left(\mathrm{CuPPh}_{3}\right)_{3}$ [24]. The average $\mathrm{Cu}-\mathrm{Br}-\mathrm{Cu}$ bond angle of $71.72(4)^{\circ}$ in 


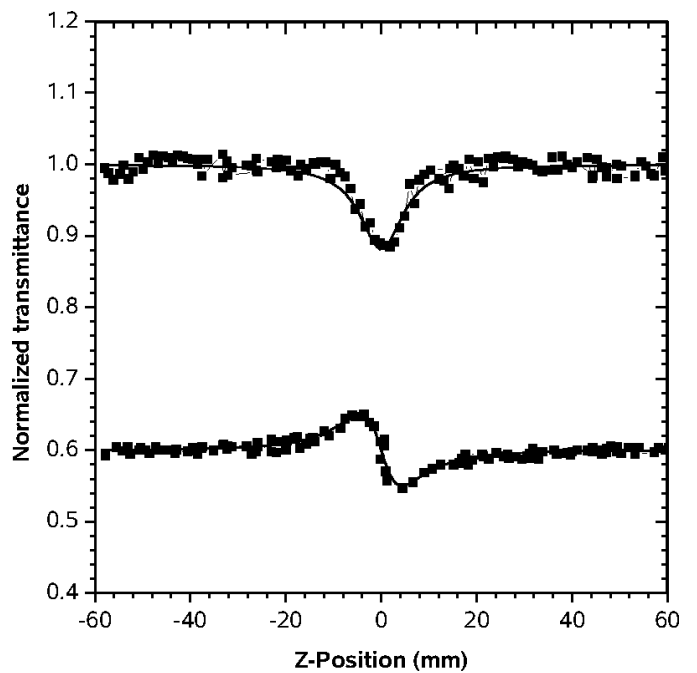

Fig. 4. $Z$-scan data of $2.15 \times 10^{-3} \mathrm{M}$ of $\mathbf{1}$ in DMF at $532 \mathrm{~nm}$ with $I_{\mathrm{o}}$ being $8.1 \times 10^{10} \mathrm{~W} \mathrm{~m}^{-2}$ collected under the open aperture configuration showing NLO absorption (above) and obtained by dividing the normalized $Z$-scan data obtained under the closed aperture configuration (below) by the normalized $Z$-scan data in the up curve. The solid curves are theoretical fits based on $Z$-scan theoretical calculations.

4. $\mathrm{MeCN}$ deviates strongly from $90^{\circ}$ as the standard cubane angle. This structural feature has also been observed in related cubane-like heteroselenometallic compounds $[6,24]$.

The electronic spectra of compounds $\mathbf{1}$ and $\mathbf{2}$ in DMF solution show intense absorption bands at $350-$ $500 \mathrm{~nm}$. The intense shoulder peaks at about 360$365 \mathrm{~nm}$ may be assigned to the $\mathrm{Se} \rightarrow \mathrm{W}$ charge transfer arising from the $\left[\mathrm{WSe}_{4}\right]^{2-}$ moiety, whereas the weaker broad bands at about $485-490 \mathrm{~nm}$ may be ascribed to a relatively weak $\left[\mathrm{WSe}_{4}\right]^{2-}$ to copper interaction [25]. It is interesting to note that the $\mathrm{Se} \rightarrow \mathrm{W}$ charge transfer transition peaks are $c a .40 \mathrm{~nm}$ blue shifted upon the structural change from trinuclear linear to tetranuclear cubane compounds, probably due to one terminal $\mathrm{W}=$ Se double bond being retained in the cubane-like compounds. Moreover, a comparison of the electronic spectra of the four compounds with that of the free $\left[\mathrm{WSe}_{4}\right]^{2-}$ anion [26] suggests that all of the bands of $\left[\mathrm{WSe}_{4}\right]^{2-}$ are shifted toward higher wavelength, thereby indicating a strong interaction between the $\left[\mathrm{WSe}_{4}\right]^{2-}$ moiety and the copper atoms.

The NLO properties of compound 1 were investigated by using the $Z$-scan technique [21]. The nonlinear absorption component was evaluated under an open aperture configuration. Theoretical curves of transmit- tance against the $Z$-position, Eqs. 1 and 2, were fitted to the observed $Z$-scan data

$$
\begin{aligned}
& T(Z)=\frac{1}{\pi^{1} / 2_{q(Z)}} \int_{-\infty}^{\infty} \ln [1+q(Z)] e^{-\tau^{2}} d \tau \\
& q(Z)=\alpha_{2} I_{i}(Z) \frac{\left(1-e^{-\alpha_{0} L}\right)}{\alpha_{0}}
\end{aligned}
$$

by varying the effective third-order NLO absorptivity $\alpha_{2}$ value, where the experimentally measured $\alpha_{0}$ (linear absorptivity), $L$ (the optical path of the sample) and $I_{i}(z)$ (the on-axis irradiance at $z$ position) were adopted. The solid line in Fig. 4 (above) is the theoretical curve calculated with $\alpha_{2}=6.11 \times 10^{-11} \mathrm{~m} \mathrm{~W}^{-1}$ for the concentration of $2.15 \times 10^{-3} \mathrm{M}$ of 1 in a DMF solution. The nonlinear refractive component plotted with the filled squares in Fig. 4 (below) was assessed by dividing the normalized $Z$-scan data obtained under the closed aperture configuration by the normalized $Z$-scan data obtained under the open aperture configuration. The valley and peak occur at about equal distances from the focus. It can be seen that the difference in valley-peak positions $\Delta Z_{\mathrm{V}-\mathrm{P}}$ is $7.3 \mathrm{~mm}$ and the difference between normalized transmittance values at valley and peak positions $\Delta T_{\mathrm{V}-\mathrm{P}}$ is 0.12 for 1 . These results suggest an effectively good third-order optical nonlinearity [24]. The solid curve is an eye guide for comparison where the effective nonlinear refractivity $n_{2}$ value estimated therefore is $4.18 \times 10^{-13}$ esu for $\mathbf{1}$. Comparing the NLO data of cluster compound 1 with that reported for $\mathrm{M}(\mathrm{W}) / \mathrm{Cu}(\mathrm{Ag}) / \mathrm{S}(\mathrm{Se})$ clusters $[12-$ $16,27]$, it may be seen that the NLO behavior of compound $\mathbf{1}$ is comparable to those of polynuclear cluster compounds. The negative value of nonlinear refraction in $\mathbf{1}$ indicates that there are self-defocusing effects in NLO behavior of the crown-like cluster compound, which is obviously different from that of cubane-like cluster compounds that show self-focusing effects of nonlinear refraction [28]. This provides evidence that the structural alterations of clusters may give rise to variations in the NLO properties [29]. More examples of heteroselenometallic cluster compounds will be synthesized for investigation of the structure/NLO property relationship.

\section{Acknowledgements}

This work was supported by the National Basic Research Program of China (973 Program, 2008CB617605) and the Program for New Century Excellent Talents in University 
of China (NCET-06-0556). W.-H. Leung thanks the Hong

Kong Research Grants Council (601506).

[1] Q. F. Zhang, W. H. Leung, X. Q. Xin, Coord. Chem. Rev. 2002, 224, 35.

[2] S. Shi, W. Ji, J.P. Lang, X. Q. Xin, J. Phys. Chem. 1994, 98, 3570 .

[3] Q.F. Zhang, Y. N. Xiong, T.S. Lai, W. Ji, X. Q. Xin, J. Phys. Chem. B 2000, 104, 3476.

[4] Y. Xiong, Q. Zhang, X. Sun, W. Tan, X. Xin, W. Ji, Appl. Phys. A 2000, 70, 85.

[5] See any issue of The Bulletin of the Selenium-Tellurium Development Association, Grimbergen, Belgium.

[6] C. C. Christuk, M. A. Ansari, J. A. Ibers, Inorg. Chem. 1992, 31, 4365 .

[7] C. C. Christuk, J. A. Ibers, Inorg. Chem. 1993, 37, 5105.

[8] R. J. Salm, J. A. Ibers, Inorg. Chem. 1994, 33, 4216.

[9] R. J. Salm, A. Misetic, J. A. Ibers, Inorg. Chim. Acta 1995, 240, 239.

[10] C. C. Christuk, M. A. Ansari, J. A. Ibers, Angew. Chem. 1992, 104, 1519; Angew. Chem., Int. Ed. Engl. 1992, $31,1477$.

[11] M. C. Hong, Q. F. Zhang, R. Cao, D. X. Wu, J. T. Chen, W. J. Zhang, H. Q. Liu, J. X. Lu, Inorg. Chem. 1997, 36,6251 .

[12] Q. F. Zhang, W. H. Leung, X. Q. Xin, H. K. Fun, Inorg. Chem. 2000, 39, 417.

[13] Q.F. Zhang, Y. Song, W. Y. Wong, W. H. Leung, X. Xin, J. Chem. Soc., Dalton Trans. 2002, 1963.

[14] Q. F. Zhang, J. Ding, Z. Yu, Y. Song, A. Rothenberger, D. Fenske, W. H. Leung, Inorg. Chem. 2006, 45, 8638.

[15] S. Miao, Z. Yu, Q. F. Zhang, Y. Song, A. Rothenberger, W. H. Leung, J. Cluster Sci. 2006, 17, 495.

[16] Q. F. Zhang, Z. Yu, J. Ding, Y. Song, A. Rothenberger, D. Fenske, W. H. Leung, Inorg. Chem. 2006, 45, 5187.
[17] S. C. O’Neal, J. W. Kolis, J. Am. Chem. Soc. 1988, 110, 1971.

[18] SMART, SAINT+ for Windows NT (version 6.02a), Bruker Analytical X-ray Instruments Inc., Madison, Wisconsin (USA) 1998.

[19] G. M. Sheldrick, SADABS, Program for Empirical Absorption Correction of Area Detector Data, University of Göttingen, Göttingen (Germany) 1996.

[20] G. M. Sheldrick, SHelXTL (version 5.1), Software Reference Manual, Bruker AXS Inc., Madison, Wisconsin (USA) 1997.

[21] M. Sheik-Bahae, A. A. Said, T. H. Wei, D. J. Hagan, E. W. Van Stryland, IEEE J. Quantum. Electron. 1990, 26,760 .

[22] Q.F. Zhang, R. Cao, M.C. Hong, D. X. Wu, W. J. Zhang, Y. Zheng, H. Q. Liu, Inorg. Chim. Acta 1998, 271, 93.

[23] Q.F. Zhang, W.H. Leung, Y.L. Song, M.C. Hong, C. L. Kennard, X. Q. Xin, New J. Chem. 2001, 25, 465.

[24] Q. F. Zhang, C. Zhang, Y. L. Song, X. Q. Xin, J. Mol. Struct. 2000, 525, 79.

[25] M. A. Ansari, C.-N. Chau, C. H. Mahler, J. A. Ibers, Inorg. Chem. 1989, 28, 650.

[26] A. Müller, E. Diemann, R. Jostes, H. Bögge, Angew. Chem. 1981, 93, 957; Angew. Chem., Int. Ed. Engl. 1981, 20, 934.

[27] H. W. Hou, X. Q. Xin, S. Shi, Coord. Chem. Rev. 1996, $153,169$.

[28] S. Shi, Z. Lin, Y. Mo, X. Q. Xin, J. Phys. Chem. 1996, 100, 10696.

[29] B. J. Coe, N. R. M. Curati, Comments Inorg. Chem. 2004, 25, 147. 